\title{
Fungal chitosan as membranous material modified by atmospheric plasma
}

\author{
Quitosana fúngica como material membranoso modificado por plasma atmosférico \\ El quitosano fúngico como material membranoso modificado por plasma atmosférico
}

Received: 12/28/2020 | Reviewed: 12/28/2020 | Accept: 12/30/2020 | Published: 01/04/2021

Weslley de Souza Paiva
ORCID: https://orcid.org/0000-0002-2022-5659
Federal University of Rio Grande do Norte, Brazil
E-mail: wdspaiva @ gmail.com
Francisco Ernesto de Souza Neto
ORCID: https://orcid.org/0000-0002-7413-2351
Nova Esperança College of Mossoró, Brazil
E-mail: fernestosn@ gmail.com
Erika de Souza Paiva
ORCID: https://orcid.org/0000-0002-7491-9242
Federal University of Piauí, Brazil
E-mail: drerikapaiva@ gmail.com
Anabelle Camarotti de Lima Batista
ORCID: https://orcid.org/0000-0002-0905-6911
Federal University of Paraiba, Brazil
E-mail: bellecamarotti@ @mail.com

\begin{abstract}
Objective: This study produced a fungal chitosan membrane extracted from Rhizopus stolonifer, as well as its modification using dielectric barrier discharge plasma (DBD), aiming to improve the physicochemical characteristics of the membrane, optimizing its use in the medical research field. Method: The obtained chitosan was physically and chemically characterized (Molecular Weight, Fourier Transform Infrared, X-ray Diffraction), later were produced fungal chitosan membranes and DBD plasma was applied. The membranes were characterized before and after plasma application using the tests contact angle, swelling and atomic force microscopy (medium roughness) analyzes. Results: A fungal chitosan with a yield of $16.73 \mathrm{mg} / \mathrm{g}$, and an apparent molecular weight of $4 \mathrm{kDa}$ was obtained, being considered of low molecular weight and high degree of deacetylation (84\%). It was possible to obtain the membrane and after application of DBD plasma, the contact angle dropped from $77.5^{\circ}$ to $30.9^{\circ}$, making it more hydrophilic. Conclusion: Thus, the efficiency of the technique for increasing the hydrophilicity of the fungal chitosan membrane without the additive of chemical reagents during the process was confirmed and the membrane formed is a promising alternative can be used in different ways in the medical area.
\end{abstract}

Keywords: Biopolymers; Rhizopus stolonifer; Fungal chitosan; Dielectric barrier discharge; DBD plasma.

\section{Resumo}

Objetivo: Este estudo produziu uma membrana fúngica de quitosana extraída de Rhizopus stolonifer, bem como sua modificação utilizando plasma de descarga de barreira dielétrica (DBD), visando melhorar as características físicoquímicas da membrana, otimizando seu uso na área de pesquisa médica. Método: A quitosana obtida foi caracterizada física e quimicamente (Peso Molecular, Transformada de Fourier no Infravermelho, Difração de Raios X), posteriormente foram produzidas membranas de quitosana fúngica e aplicado plasma DBD. As membranas foram caracterizadas antes e após a aplicação do plasma por meio dos testes de ângulo de contato, intumescimento e microscopia de força atômica (rugosidade média). Resultados: Foi obtida uma quitosana fúngica com rendimento de $16,73 \mathrm{mg} / \mathrm{g}$, e peso molecular aparente de $4 \mathrm{kDa}$, sendo considerada de baixo peso molecular e alto grau de desacetilação (84\%). Foi possível obter a membrana e após a aplicação do plasma DBD, o ângulo de contato caiu de $77,5^{\circ}$ para $30,9^{\circ}$, tornando-o mais hidrofílico. Conclusão: Assim, foi confirmada a eficiência da técnica para aumentar a hidrofilicidade da membrana fúngica de quitosana sem o aditivo de reagentes químicos durante o processo e a membrana formada é uma alternativa promissora podendo ser utilizada de diferentes formas na área médica.

Palavras-chave: Biopolímeros; Rhizopus stolonifer; Quitosana fúngica; Descarga de barreira dielétrica; Plasma DBD.

\section{Resumen}

Objetivo: Este estudio produjo una membrana fúngica de quitosano extraída de Rhizopus stolonifer, así como su modificación mediante plasma de descarga de barrera dieléctrica (DBD), con el objetivo de mejorar las características físico-químicas de la membrana, optimizando su uso en el campo de la investigación médica. Método: El quitosano obtenido se caracterizó física y químicamente (Peso Molecular, Transformación de Fourier en infrarrojos, Difracción de Rayos X), posteriormente se produjeron membranas de quitosano fúngico y se aplicó plasma DBD. Las 
membranas se caracterizaron antes y después de la aplicación del plasma mediante ensayos de ángulo de contacto, hinchamiento y microscopía de fuerza atómica (rugosidad media). Resultados: Se obtuvo un quitosano fúngico con un rendimiento de $16,73 \mathrm{mg} / \mathrm{gy}$ un peso molecular aparente de $4 \mathrm{kDa}$, considerándose de bajo peso molecular y alto grado de desacetilación (84\%). Se pudo obtener la membrana y luego de aplicar el plasma DBD, el ángulo de contacto bajó de $77.5^{\circ}$ a $30.9^{\circ}$, haciéndola más hidrofílica. Conclusión: Así, se confirmó la eficacia de la técnica para incrementar la hidrofilicidad de la membrana fúngica de quitosano sin la adición de reactivos químicos durante el proceso y la membrana formada es una alternativa prometedora que puede ser utilizada de diferentes formas en el campo médico.

Palabras clave: Biopolímeros; Rhizopus stolonifer; Quitosano fúngico; Descarga de barrera dieléctrica; Plasma DBD.

\section{Introduction}

The Chitosan is a copolymer formed from the deacetylation of some chitin glycopyranose residues (Annu et al., 2017). It has 2-acetamido-2-deoxy-D-glycopyranose and 2-amino-2-deoxy-D-glycopyranose units. However, this molecule is only considered a chitosan when more than $50 \%$ of the polymers residues are 2-amino-2-deoxy-D-glycopyranose (Anwar et al., 2017). When chemically obtained from the chitin present in crustacean carapace it is known as an animal chitosan (Polymar, 2020). Futhermore, chitosan can be also obtained by extracting directly from the fungal cell wall, especially those belonging to the Zygomycetes fungal class (Paiva et al., 2017). Animal chitosan is the most commercially used because its yield is approximately 2 to 3 times higher than the fungal. However, their purification and processing require a large amount of use of chemical compounds, which elevate the costs of production and decreases the yield (Bento et al., 2011). In addition, animal chitosan depends on the seasonal factors of the region where the crustacean is reared, making product standardization and industrial scale implementation difficult (Ghormade et al., 2017). When referring to food and medical use, another problem is suggested: The allergenic potential of some proteins such as tropomyosin and arginine kinase that accumulate in the chitosan molecule when not properly purified (Stamford et al., 2007; Pascal et al., 2015; Faber et al., 2017).

The use of fungi for chitosan production has some advantages over the traditional process. (1) The fungi can be cultivated with simple and inexpensive substrates, such as industrial waste and food, reducing process costs; (2) fungal chitosan can be produced during the year with no restrictions when using a controlled environment, this way ensuring continuous production (3) It has low rates of calcium and other ions, which reduces the risk of mineral accumulation in the body (Arcidiacono et al., 1989; Synowiecki \& Ali-Khateeb, 2003; Queiroz et al., 2015; Batista et al., 2018).

In recent years, some studies have shown the potential of fungal chitosan, such as antifungal, antibacterial, anticancer and antiparasitic action (Paiva et al., 2014; Souza Neto et al., 2017; Almutairi et al., 2020; Batista et al., 2020; Sathiyaseelan et al., 2020). For these reasons, fungal chitosan is already being produced and marketed by companies in different countries, such as Belgium, Canada and the United States. All for medical and / or pharmaceutical applications (Kitozyme, 2020; Mycodev, 2020).

Studies have shown that the degree of deacetylation and molecular weight of chitosan has a directly influence on the absorption of liquids, the higher the degree of deacetylation (between 80-90\%) and molecular weight, the higher the rate of water absorption (Schipper et al., 1996; Pankaj, 2015; Chumwangwapee et al., 2016). This is explained by the predominance of amino groups in chitosan that give this biopolymer a high polarity (Assis et al., 2002).

Due to interferences of physicochemical characteristics, to maintain the various possibilities of use of biomaterials, some modifications are required. Conventional biomaterial modification techniques are solvent treatments, acid-base solutions, mechanical abrasion and chemical activation, favoring polysaccharide parameterization processes, chain oscillations and toxic waste production.

To solve the problems of conventional techniques, the use of cold atmospheric plasma, a weakly ionized gas that operates under atmospheric conditions below $40{ }^{\circ} \mathrm{C}$, has emerged. Under these conditions, only a small fraction of major heatbearing atoms and gas molecules collide with electrically energetic electrons, resulting in increased excitation, ionization, and 
dissociation, while the plasma remains "cold" (Klampl et al., 2012). Among the chemical clusters identified in atmospheric plasma are molecules $(\mathrm{OH}, \mathrm{NO}, \mathrm{CN}, \mathrm{O} 3)$, atomic radicals $(\mathrm{H}, \mathrm{O}, \mathrm{N})$, and other species of active groups: such as $\mathrm{N} 2+$, which has properties that the gas alone doesn't have, such as magnetism and conductivity (Machala et al., 2007).

Treating materials with atmospheric plasma give to the materials characteristics for their use in different areas. Among these characteristics are: (1) ability of its action to be restricted to the surface of materials without affecting their mechanical properties; (2) introduction of reactive radicals and their conversion into functional groups; (3) do not require high cost vacuum or compression systems; (4) be environmentally friendly as its use generates less environmentally toxic compared to chemical methods of material modification; (5) antimicrobial effect of Escherichia coli and Bacillus subtilis endospores, Staphylococcus aureus and Clostridium difficile cells (Hegemann et al., 2003; Hong et al., 2009; Chen et al., 2010; Salem et al., 2011; Sasmazel, 2011; Galvin et al., 2013; Shahidi et al., 2015; Ren et al., 2017).

One of the most versatile types of atmospheric plasma is dielectric barrier discharge (DBD) plasma, which consists of a discharge occurring in a space between two metal electrodes, where at least one dielectric are inserted between these electrodes. By adding a potential difference between the electrodes, the electric charges begin to accumulate on the dielectric surface. At some point, the charge accumulation on the surface reaches its limit, breaking the dielectric rigidity of the gas, causing micro-discharge, which is what we call plasma. This process is repeated every half cycle of the applied voltage pulse between the metal electrodes (Bogaerts et al., 2002).

DBD has been shown to be an effective method for producing homogeneous unbalanced plasma at atmospheric pressure with simple operation system. Surface modification of materials such as grafting, surface cleaning and hydrophilic polymer modification, powders and seed surface modification is widely used (Morent et al., 2011; Molina et al., 2014). In a view of the diversity of applications of fungal chitosan and the advantages of the treatment of biopolymers by dielectric barrier discharge plasma. The present work aims to treat fungal chitosan membranes with atmospheric plasma in order to observe how the membrane hydrophilicity and liquid absorption, will behave after the treatment. Thus, we intend Aiming to potentiate the use of fungal chitosan, leaving it in optimal conditions for the application in different medical areas.

\section{Methodology}

\subsection{Fungal Collection, Cultivation and Chitosan Extraction}

Soil samples were collected at 10 different points of the ESEC Seridó reserve (Seridó Ecological Station), under the license number 36672-1 SISBIO / ICMBio, in the county of Serra Negra do Norte / RN / Brazil, at the geographic coordinates $06^{\circ} 35^{\prime}$ e $06^{\circ} 40^{\prime}$ South, and $37^{\circ} 20^{\prime}$ and $37^{\circ} 39^{\prime}$ West. After monospore growth, the fungi were isolated and identified as Rhizopus stolonifer (Vital \& Zilli 2010).

Petri dishes with BDA synthetic medium (Potato Dextrose Agar) and monospore growth were incubated at $28^{\circ} \mathrm{C}$ for 72 hours. The spores were collected and stored in $15 \mathrm{~mL}$ of sterile distilled water (standard solution). About $105 \mathrm{spores} / \mathrm{mL}$ of the standard solution were added in $400 \mathrm{~mL}$ of YPD (Yeast Extract $10 \mathrm{~g}$; Peptone $20 \mathrm{~g}$; Dextrose $20 \mathrm{~g}$ per liter) and incubated at $28^{\circ} \mathrm{C} / 96$ hours in static mode (Stamford et al., 2007). Biomass was filtered, lyophilized, and chitosan was extracted according Hu et al. (1999).

\subsection{Fungal chitosan Characterization}

Size exclusion chromatography was applied to determine the apparent molecular weight of chitosan. 7.8 x $300 \mathrm{~mm}$ Ultrahydrogel 500 and 250 columns (Waters Corp., Milford, Massachusetts, USA), connected in series, were coupled to an Accela ${ }^{\circledR}$ refractive index detector HPLC (Thermo Scientific, Waltham, Massachusetts, USA). The eluent was filtered $(0.22$ $\mu \mathrm{m}$ membrane) in ultrapure water with $0.1 \mathrm{M} \mathrm{NaNO}$, with a flow rate of $0.6 \mathrm{~mL} / \mathrm{min}$ at $30^{\circ} \mathrm{C}$. A set of dextran standards $(4$, 
$6,10,40,72.1,147$ and $270 \mathrm{kDa}$ ) was used to construct the standard curve and to determine the apparent molecular weight of the biopolymer (Galinari et al., 2017).

Fourier Transform Infrared Spectroscopy (FTIR) were performed with a Shimadzu spectrophotometer model IR Prestige-21, with attenuated total reflectance accessory (from English, ATR) coupled with the following analysis conditions: Region 4000 - $600 \mathrm{~cm}-1$; Resolution: $4 \mathrm{~cm}-1$; Accumulations: 20; Mode: transmittance. For the checking the degree of deacetylation of the samples, formula (1) was applied (Brugnerotto, 2001).

$$
\begin{aligned}
& \mathrm{DA}=[(\mathrm{A} 1320 / \mathrm{A} 1420)-0,3822] / 0,03133 \\
& \mathrm{DD}=100-\mathrm{DA}
\end{aligned}
$$

X-ray diffraction measurements were performed based on the technique of Signini \& Campana Filho (2001) with modifications. It was used a SHIMADZU X-ray diffractometer (Model XRC-6000) with copper tube $(\lambda=1.54 \AA$ ). The voltage and current used were of the order of $40 \mathrm{kV}$ and $40 \mathrm{~mA}$, respectively. These measurements were performed at a range of 3-50 ${ }^{\circ} \mathrm{C}$ with a scan rate of $1^{\circ} /$ minute in $0.02^{\circ}$ steps (Signini \& Campana Filho, 2001).

\subsection{Biomembrane Production and Application of the Dielectric Barrier Discharge Plasma (DBD)}

The powder was dissolved in $2 \%$ acetic acid with constant stirring for 24 hours. After this period, the chitosan solution were filtered twice, the first time with a nylon filter and the second with a $0.45 \mathrm{~mm}$ filter (Millipore, Billerica, MA, USA) (Macedo et al., 2012).

The application of plasma to fungal chitosan membranes was performed according to the methodology proposed by Napartovich et al. (2001) with modifications. Plasma was generated using $1 \mathrm{~L} / \mathrm{min}$ flow Helium gas and applied as describes in Table 1. The dielectric barrier discharge plasma generation system can be seen in Paiva (2017).

Table 1: Parameters of dielectric barrier plasma (DBD) applications and the relationships between wettability and

\begin{tabular}{|c|c|c|c|}
\hline Treatments & Voltage $(k V) / T i m e(\min ) *$ & Wettability & Average roughness (nm) \\
\hline 1 & $15 / 10$ & $69.5^{\circ} \pm 0.51^{\mathrm{a}}$ & $624.76 \pm 7.37^{b}$ \\
\hline 2 & $15 / 5$ & $39.5^{\circ} \pm 0.57^{b}$ & $1346.05 \pm 5.84^{\mathrm{b}}$ \\
\hline 3 & $15 / 1$ & $30.9^{\circ} \pm 0.57^{b}$ & $2118.78 \pm 2.31^{\mathrm{a}}$ \\
\hline 4 & $30 / 10$ & $64.0^{\circ} \pm 0.50^{\mathrm{a}}$ & $732.82 \pm 4.59^{b}$ \\
\hline 5 & $30 / 5$ & $58.5^{\circ} \pm 0.80^{\mathrm{a}}$ & $1023.57 \pm 2.72^{b}$ \\
\hline 6 & $30 / 1$ & $57.3^{\circ} \pm 0.56^{\mathrm{a}}$ & $847.25 \pm 2.61^{b}$ \\
\hline 7 & No treatment & $77.5^{\circ} \pm 0.82^{\mathrm{a}}$ & $668.30 \pm 3.43^{\mathrm{b}}$ \\
\hline
\end{tabular}
average roughness for the different treatments analyzed.

${ }^{*}$ All tests were at the frequency of $500 \mathrm{~Hz}$; a; b Different letters denote statistically different data. Source: Authors.

\subsection{Characterization of the Chitosan Membrane}

For the analysis of the wettability, the sessile drop method was chosen, where a drop was deposited on the surface of 
the sample. The samples were placed on the flat base and then a drop of $10 \mu \mathrm{l}$ of distilled water was deposited on the surface of the membranes. The researchers monitored the process in real time, and saved it on a computer using the Surftens 4.5 software. After, the images were saved for the desired instants: 0, 10, 20, 30, 40, 50 and 60 seconds and analyzed by the same software. The contact angle values presented in this study reflected the average of the measurements of three images. Five measurements were taken for each image (Alves Jr. et al., 2016).

The degree of swelling or absorption of the fungal chitosan membranes was evaluated by immersing them in PBS solution (Phosphate Buffered Saline $\mathrm{pH}$ 7.4). The test was performed in triplicate for each assay. After a 24-hour immersion period the samples were removed from the PBS solution and weighed in analytical balance (excess liquid was removed with paper towels). Each membrane was weighed 4 times to reduce the risk of weighing errors.

The degree of swelling was evaluated as the mass percentage gain of the wet samples and was calculated by:

Equation 2

Loss of Mass $(\%)=[($ inicial mass - final mass $) /$ inicial mass $] \times 100$

To analyze the roughness and topography of the chitosan membrane samples, a Shimadzu Corp. atomic force microscope, model SPM-9600 (Japan) was used. The equipment was used in dynamic or intermittent mode at a scan rate of 1 Hz. Random areas of $10 \mu \mathrm{m} \times 10 \mu \mathrm{m}$ were scanned and analyzed by SPM Manager software Version 3.4 (Japan). The parameters of arithmetic average roughness (Ra) were analyzed. The analysis of the topography was done through the 3D images obtained in the AFM (Macedo et al., 2012).

\subsection{Statistical analysis}

For the statistical analysis of the contact angles and mean roughness, the ANOVA test was used to measure the variability between the values and then the Tukey test was used to evaluate if there was a significant difference between the means. The researchers performed all tests in triplicate and analyzed by the PAST program.

\section{Results and Discussion}

\subsection{Characterization of fungal chitosan}

The edaphic samples from Seridó Ecological Station was identified as R. stolonifer and it generated a yielded of chitosan of $16.73 \mathrm{mg} / \mathrm{g}$ by dry biomass. The chitosan produced was characterized with molecular weight of $4.12 \mathrm{kDa}$, degree of deacetylation of $84 \%$. The molecular weight obtained by a High-performance liquid chromatography and stable in solution, was characterized. Indicating whether it is a polymer with a low molecular weight and a low colloid formation capacity.

These results contrast with those found by Cardoso et al. (2012) and Berger et al. (2018) within a respective yield of $29.3 \mathrm{mg} / \mathrm{g}$ and $49.31 \mathrm{mg} / \mathrm{g}$ of chitosan for R. arrhizus. Although they are all from the same class of Zygomycetes, they have specific genetic differences and the carbon and nitrogen source used in the culture medium may also have influenced the production of fungal chitosan.

\subsubsection{Fourier Transform Infrared and X-ray}

The Fourier transform infrared characterize the chitosan as for the degree of deacetylation (DD) and it is considered one of the most important chemical characteristics that can influence solubility, chemical reactivity and biodegradability. Fungal chitosan with high degree of deacetylation has a high-density positive charge due to the free amine groups, making it unique for several biological applications (Berger et al., 2014; Abdel Gaward et al., 2017). Freier et al. (2005) demonstrated 
how this degree favors a low degradation of the biopolymer, as well as the cell adhesion when close to a $100 \%$. Huang et al. (2004) showed that the greater the degree of deacetylation, the greater the absorption of nanoparticles by fibroblasts in cell culture.

The DD of $84 \%$ estimated by the FT-IR in this study characterizes the polymer as chitosan, according to the EUCHIS (European Chitin Society) (Figure 1A). Indicating that this biopolymer has few protonated groups in its chain and has an amine group in the carbon 2 in more than 60\% of its residues (Zhang et al., 2017). These results are similar to those obtained by Gharieb et al. (2015) who produced chitosan from the fungi species Mucor rouxxi, Rhizopus sp., Cunninghamella elegans, with DD of $80.3 \%, 81.5 \%, 80.3 \%$, respectively. However, compared to the degree of deacetylation of others fungi chitosan, the results contrast with the ones found by Mondala et al. (2015) and Zimoch-Korzycka et al. (2016) who obtained a degree of deacetylation of $60 \%$ and $72 \%$, respectively, using Mucor rouxxi, and Aspergillus niger. These contrasts indicate that the degree of deacetylation varies with the type of fungus and the culture medium, and this variation can be about $30 \%$. It is important to note that there are no studies to characterize the fungus Rhizopus stolonifer, so the comparisons are between others same fungi class, Zygomycetes.

The X-ray diffraction in the sample extracted from Rhizopus stolonifer, demonstrated the presence of a peak around $20^{\circ}$ indicating the crystalline region of the material, and a $9^{\circ}$ peak indicating the amorphous region of chitosan (Figure 1B).

The results of diffraction Raio-X corroborate with studies founded which confirm these peaks as characteristic regions of chitosan, be it fungal or animal. Associated with the FT-IR result, it is indicated that the extracted polymer is effectively chitosan (Berger et al., 2014; Berger et al., 2018; Zhang et al., 2017).

Figure 1. Structural analysis of the fungal chitosan molecule by using the Fourier transform infrared spectroscopy technique (A) and X-ray diffraction technique (B). (A) Peaks $\sim 3378.25 \mathrm{~cm}^{-1}$ (O-H stretch), $\sim 2922.00 \mathrm{~cm}^{-1}$ (C-H stretch), 1644.94 (carbonyl group C = O (amide I)), 1417.14 (amide I and II) and $\sim 1030.49 \mathrm{~cm}^{-1}$ (saccharide structure). (B) Peak around $20^{\circ}$ indicating the crystalline region and a $9^{\circ}$ peak indicating the amorphous region of fungal chitosan.

\section{A}

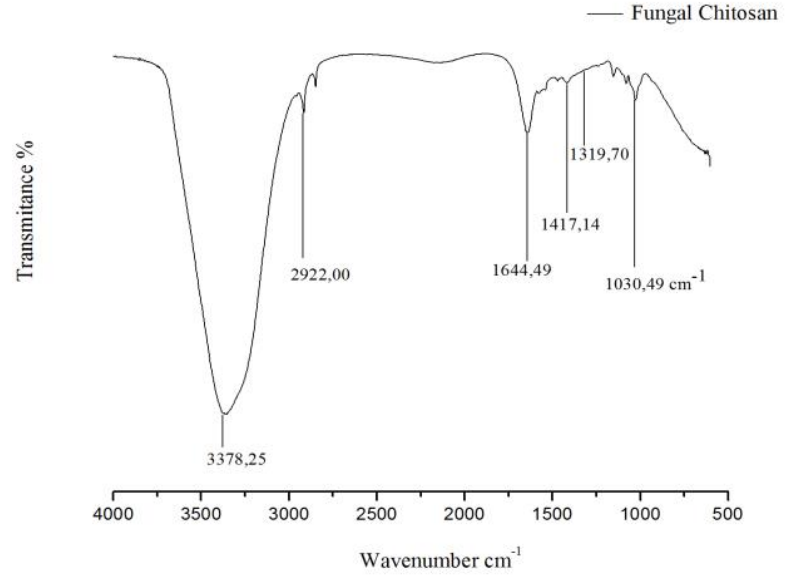

Source: Authors (2020).

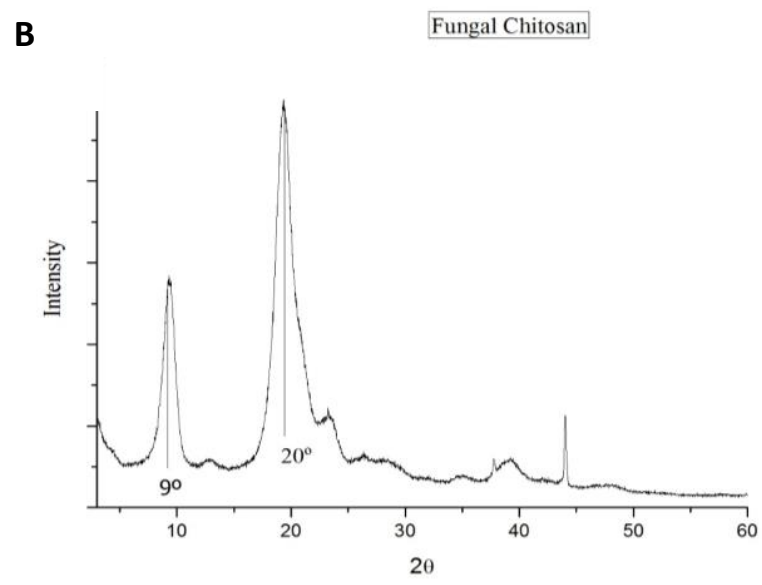

\subsection{Production and characterization of the fungal chitosan membrane}

The chitosan membrane was produced according to the proposed methodology and afterwards it was divided into pieces measuring $2 \times 2 \mathrm{~cm}$ to carry out the characterizations before and after treatment by DBD plasma (Figure 2). 
Figure 2. Membranous chitosan biomaterial extracted from Rhizopus stolonifer.

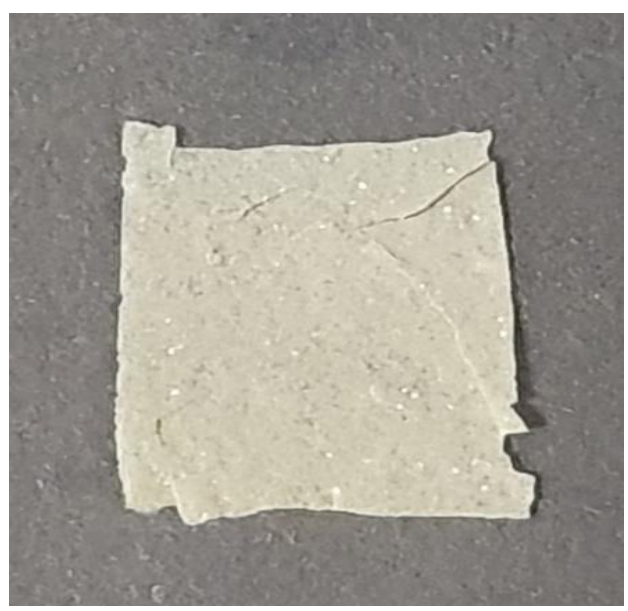

Source: Authors (2020).

The treatments 2 and 3 (describes in Table 1) obtained a significant lower contact angle than the untreated sample, indicating that atmospheric plasma increased wettability in those specific conditions (Figure 3).

Figure 3. Contact angle measurements of fungal chitosan membrane samples after treatment under different Dielectric Barrier Discharge plasma (DBD). All the tests were at the frequency of $500 \mathrm{~Hz}$. *Assay 7 is the untreated DBD sample and different letters denote statistically different data.

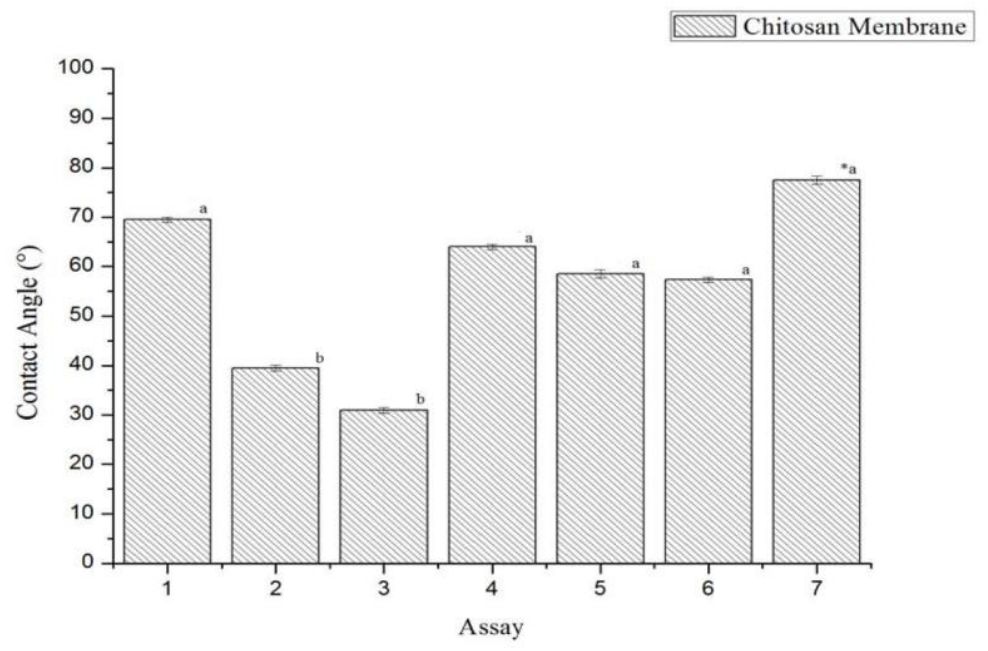

Source: Authors (2020).

Statistical analysis of the data indicated a significant difference $(\mathrm{p}<0.05)$ between the contact angles of treatments 2 and 3, in comparison to the others, showing that the treatments had the better effect. When performing the Tukey test, the difference between the contact angles was obtained on the 6 different treatments.

The measurement of the contact angle of a liquid with the surface of a sample has its importance in the correlation of solubility of that sample in that liquid. Based on this idea, the use of DBD plasma in chitosan membranes favor the incorporate 
polar functional groups on these surface, which can alter its absorption capacity and interfere in the contact angle.

Zhang et al. (2012) demonstrated, through mass spectrometry, that when using DBD plasma formed by helium gas there is a promotion of the formation of a larger number of reactive groups that act modifying the surface and leaving the surface layer of the membrane more hydrophilic. Among these reactive groups are: $\mathrm{N}+, \mathrm{O}+, \mathrm{OH}+, \mathrm{H} 2 \mathrm{O}+, \mathrm{H} 3 \mathrm{O}+, \mathrm{N} 2+, \mathrm{N} 2 \mathrm{H}+$, $\mathrm{NO}+, \mathrm{O} 2+, \mathrm{N} 2 \mathrm{O}+, \mathrm{NO} 2+, \mathrm{O}-, \mathrm{OH}-, \mathrm{H} 3 \mathrm{O}-, \mathrm{O} 2-, \mathrm{NO} 2-, \mathrm{O} 3-$, O-(H2O)2, $\mathrm{CO} 3-, \mathrm{HCO} 3-, \mathrm{NO} 3-$.

In addition to helium gas experiments some authors are using atmospheric air at room temperature. Theapsak et al. (2012) and Dorraki et al. (2015) managed to promote the formation of polar reactives on the surface of membranes containing oxide polyethylene and animal chitosan. These authors demonstrated that a reduction of $50.52 \%$ and $40.57 \%$, respectively, in the contact angle for solubilization in water when under conditions $15 \mathrm{kV} / 10 \mathrm{sec} / 350 \mathrm{~Hz}$ and $14 \mathrm{kV} / 6 \mathrm{~min} / 6 \mathrm{~Hz}$, respectively. Thus, they indicate the availability of using DBD plasma in the preparation of membranes containing chitosan for medical and food use among others. In our study, the better treatment the contact angle going from $77.5^{\circ}$ to $30.9^{\circ}$, a reduction of $39.87 \%$ (15 kV / $1 \mathrm{~min} / 500 \mathrm{~Hz}$ treatment 3, Table 1 ) demonstrates the economic viability of using this technique to also increase the hydrophilicity of a fungal chitosan membrane.

An increase in the wettability of a membrane favors the hypothesis of its great importance for a drug delivery application. Such an application requires a material that readily absorbs the drug to be applied, in other words, to a more hydrophilic material.

To demonstrate the effects of plasma on the surface of the fungal chitosan membrane, an atomic force microscopy was performed on the membranes. The average roughness of the samples was measured and this analysis being the average of the peaks found on the surface of the treatment.

The untreated membrane had an average roughness of $668.61 \mathrm{~nm}$, with topography with peaks concentrated in a single region (Figure 4A). The treatment 3 (Figure 4B) resulted in a higher average roughness value of the fungal chitosan membrane, reaching a value of $2118.78 \mathrm{~nm}$, showing an increase in roughness after treatment with DBD plasma.

The increase of the average roughness indicates a surface modification of the membranous material, which is also evidenced by the topographic modification visible in the images, related to the wettability. The results demonstrate that the higher the average roughness, the greater the wettability of the membrane, in other words, the more hydrophilic the membrane will be (Table 1).

Our data contrast with the work of Marques et al. (2016) which obtained a mean roughness of $4.0 \mathrm{~nm}$ of membrane produced from animal chitosan with a degree of deacetylation of $88 \%$. The studies of Cleymand et al. (2016) which obtained a mean roughness of $9.32 \mathrm{~nm}$ in the animal chitosan membrane with $85.9 \%$ deacetylation associated with nanoliposomes; and with Tamburaci \& Tihminlioglu (2017), obtained a result of $2.38 \mathrm{~nm}$ for roughness of the composite of chitosan animal and diatomite. These differences can be explained by the origin of chitosan, degree of deacetylation, molecular weight and mode of obtaining the membrane. Since, according to its characteristics, the polymer can behave in different ways. A high degree of deacetylation (above 70\%) influences permeation and absorption, thus increasing the average roughness (Pankaj, 2015). Macedo et al. (2012) obtained chitosan membranes with high roughness when treated with a low pressure plasma with different atmospheres. The results were 4800, 5911 and $5062 \mathrm{~nm}$ for the atmospheres of (O2, N2, H2), respectively. When nitrogen plasma was used, the surface of the membrane became more uneven, demonstrating that there was more superficial modification of the membrane. 
Figure 4. Atomic Force Microscopy (AFM) of fungal chitosan: (A) without treatment (assay 7) and (B) treatment $15 \mathrm{kV} / 1 \mathrm{~min} / 500 \mathrm{~Hz}$ (assay 3).

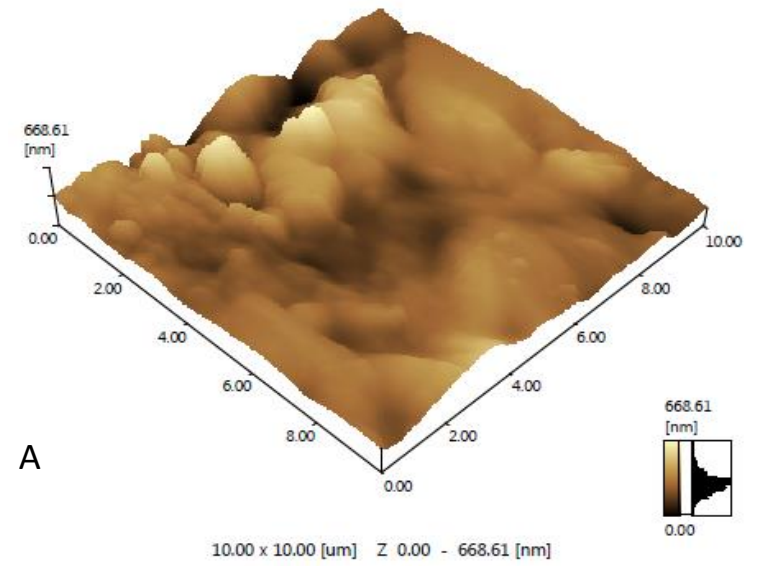

$10.00 \times 10.00[\mathrm{um}] \quad \mathrm{z} 0.00-668.61[\mathrm{~nm}]$

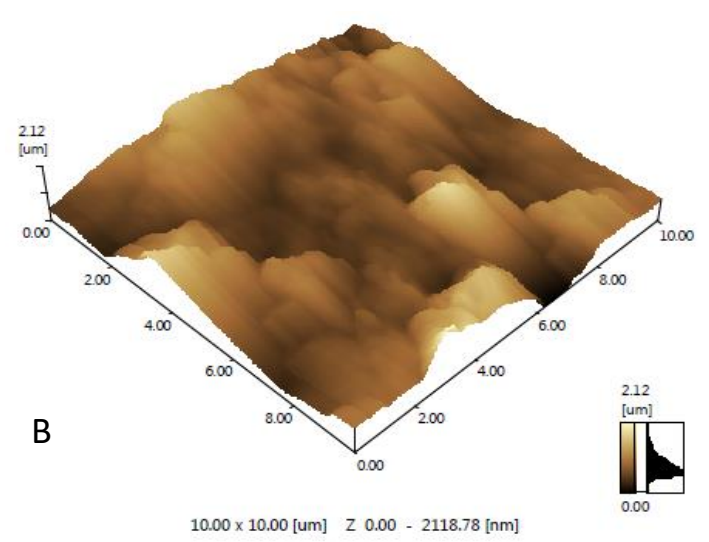

$10.00 \times 10.00[\mathrm{um}] \quad \mathrm{Z} 0.00-2118.78[\mathrm{~nm}]$

Source: Authors (2020).

\section{Conclusion}

According to the results, it was possible to obtain a good quality chitosan from the fungi Rhizopus stolonifer, as well as its transformation into membranous material. In addition, the use of the DBD plasma technique at room temperature with atmospheric air for the addition of polar chemical reagents resulted in an increase in the average of the roughness and wettability of the formed membrane. Thus, the efficiency of the technique to increase the hydrophilicity of the chitosan fungal membrane without the addition of chemical reagents during the process has been confirmed and the formed membrane is a promising alternative that can be used in different ways in the medical field.

For additional analysis, we suggested in vitro tests with the membranous to confirm its antimicrobial potential, cellular regeneration and cellular adhesion as described by literature for different membranous of chitosan (Braga et al., 2019; Rosendo et 1., 2020).

\section{Credit authorship contribution statement}

The work was carried out jointly in association with authors from different universities and areas, with the following division of tasks: Conceptualization - Weslley de Souza Paiva; Data curation - Weslley de Souza Paiva; Formal analysis Weslley de Souza Paiva, Francisco Ernesto de Souza Neto and Erika de Souza Paiva; Funding acquisition - Anabelle Camarotti de Lima Batista; Investigation - Weslley de Souza Paiva; Methodology - Anabelle Camarotti de Lima Batista, Weslley de Souza Paiva and Francisco Ernesto de Souza Neto; Project administration - Anabelle Camarotti de Lima Batista; Resources - Anabelle Camarotti de Lima Batista; Software - Anabelle Camarotti de Lima Batista, Weslley de Souza Paiva and Francisco Ernesto de Souza Neto; Supervision - Anabelle Camarotti de Lima Batista; Validation - Anabelle Camarotti de Lima Batista, Weslley de Souza Paiva, Francisco Ernesto de Souza Neto and Erika de Souza Paiva; Visualization - Anabelle Camarotti de Lima Batista, Weslley de Souza Paiva, Francisco Ernesto de Souza Neto and Erika de Souza Paiva; Writing original draft - Weslley de Souza Paiva; Writing - review \& editing - Anabelle Camarotti de Lima Batista, Weslley de Souza Paiva, Francisco Ernesto de Souza Neto and Erika de Souza Paiva. 


\section{Acknowledgments}

To Coordination for the Improvement of Higher Education Personnel (CAPES - Brazil) for the scholarships; to Federal Rural University of Semiarido (UFERSA), Mossoró, Rio Grande do Norte; and to Federal University of Paraiba (UFPB), Bananeiras, Paraiba, for being of great importance for the execution of the research.

\section{Conflicts of Interest}

The authors declare no conflict of interest.

\section{References}

Almutairi, F. M., El Rabey, H. A., Tayel, A. A., Alalawy, A. I., Al-Duais, M. A., Sakran, M. I. \& Zidan, N. S. (2020). Augmented anticancer activity of curcumin loaded fungal chitosan nanoparticles. Int J Biol Macromol, 155, 861-867.

Alves Jr, C., Vitoriano, J. O., Silva, D. L. S., Farias, M. L. \& Dantas, N. B. L. (2016). Water uptake mechanism and germination of Erythrina velutina seeds treated with atmospheric plasma. Sci Rep, 6, 1-7.

Annu, S. A., Ahmed, S. \& Ikram, S. (2017). Chitin and chitosan: history, composition and properties. In Chitosan: derivatives, composites and applications, Ed. Ahmed, S., Ikram, S., Beverly, M. A: Scrivener Publishing, Wiley.

Anwar, M., Anggraeni, A. S. \& Al Amin, M. H. (2017). Comparison of green method for chitin deacetylation Cite as: AIP Conference Proceedings, 1823, 020071-1.

Assis, O. B. G., Vieira, D. C., Vasques, R. A. \& Campana-Filho, S. P. (2002). Formed-in-place chitosan-carboxymethyl cellulose supported microfiltration membranes for water purification. in: Proceedings of the 4th ISNAPOL (Natural Polymers and Composites IV), $2002,341$.

Arcidiacono, S., Lombardi, S. J. \& Kaplan, D. L. (1989). Fermentation, processing and enzyme characterization for chitosan biosynthesis by Mucor rouxii. In: Sjak-Braek, G., AnthonseN, T., Sandford, P. Chitin and chitosan: sources, chemistry, biochemistry, physical properties and applications. Elsevier, 1989.835.

Batista, A. C. L., Souza Neto, F. E. \& Paiva, W. S. (2018). Review of fungal chitosan: past, present and perspectives in Brazil. Polímeros, $28,275-283$.

Batista, A. C. L., Melo, T. B. L., Paiva, W. S., Souza, F. S., \& Campos-Takaki, G. M. (2020). Economic microbiological conversion of agroindustrial wastes to fungi chitosan. An Acad Bras Ciênc, 92, 1-13.

Bento, A. R., Stamford, T. L. M., Stamford, T. C. M., Andrade, S. A. C. \& Souza, E. L. (2011) Sensory evaluation and inhibition of Listeria monocytogenes in bovine pâté added of chitosan from Mucor rouxii. Leb-WissenTech, 44, 588-591.

Berger, L. R. R., Stamford, T. C. M., Stamford-Arnaud, T. M., Alcantara, S. R., Silva, A. C., Silva, A. M., Nascimento, A. E. \& Campos-Takaki, G. M. (2014). Green conversion of agroindustrial wastes into chitin and chitosan by Rhizopus arrhizus and Cunninghamella elegans strains. Int J Mol Sci, 15, 90829102 .

Berger, L. R. R., Stamford, T. C. M., Oliveira, K. A. R., Pessoa, A. M. P., Lima, M. A. B., Pintado, M. M. E., Câmara, M. P. S., Franco, L. O., Magnani, M. \& Souza, E. L. (2018). Chitosan produced from mucorales fungi using agroindustrial by-products and its efficacy to inhibit colletotrichum species. Int $J$ Biol Macromol, 108, 635-641.

Bogaerts, A., Neyts, E., Gijbels \& Mullen, R. J. V. (2002). Gas discharge plasmas and their applications. Spectrochim Acta Part B at Spectrosc, $57,609-658$.

Braga, L. A. S., Flauzino Junior, A., González, M. E. L., \& Queiroz, A. A. A. de. (2019). Membranas termossensíveis baseadas em redes poliméricas semiinterpenetrantes de Quitosana e Poli(N-isopropilacrilamida). Res Soc Dev, 8, e3883748.

Brugnerotto, J., Lizardi, J., Goycoolea, F. M., Argüelles-Monal, W., Desbrières, J., \& Rinaudo, M. (2001). An infrared investigation in relation with chitin and chitosan characterization. Polymer, 42, 3569-3580.

Cardoso, A., Lins, C. I., Santos, E. R., Silva, M. C. \& Campos-Takaki, G. M. (2012). Microbial enhance of chitosan production by Rhizopus arrhizus using agroindustrial substrates. Molecules, 17, 4904-4914.

Chen, C., Ogino, A., Wang, X. \& Nagatsu, M. (2010). Plasma treatment of multiwall carbonnanotubes for dispersion improvement in water, Appl Phys Lett, 96, 131504-131504-2.

Chumwangwapee, S., Chingsungnoen, A. \& Siric, S. A. (2016). A plasma modified cellulose-chitosan porous membrane allows efficient DNA binding and provides antibacterial properties: A step towards developing a new DNA collecting card. Forensic Sci Int Genet, $25,19-25$.

Cleymand, F., Zhang, H., Dostert, G., Menu, P., Arab-Tehrany, E., Velot, E. \& Mano, J. F. (2016). Membranes combining chitosan and natural-origin nanoliposomes for tissue engineering. RSC, 6, 83626-83637.

Dorraki, N., Safa, N. N., Jahanfar, M., Ghomi, H. \& Ranaei-Siadat, S. (2015). Surface modification of chitosan/PEO nanofibers by air dielectric barrier discharge plasma for acetylcholinesterase immobilization. Appl Surf Sci, 349, 940-947.

Faber, M. A., Pascal, M., El Kharbouchi, O., Sabato, V., Hagendorens, M. M., Decuyper, I. I., Bridts, C. H. \& Ebo, D. G. (2017). Shellfish allergens: tropomyosin and beyond. Allergy, 72, 842-848. 
Freier, T., Koh, H. S., Kazazian, K. \& Shoichet, M. S. (2005). Controlling cell adhesion and degradation of chitosan films by N-acetylation. Biomaterials, 26, $5872-5872$

Galinari, E., Sabry, D. A., Sassaki, G. L., Macedo, G. B., Passos, F. M. L., Mantovani, H. C. \& Rocha, H. A. O. (2017). Chemical structure, antiproliferative and antioxidant activities of a cell wall $\alpha$-d-mannan from yeast Kluyveromyce marxianus. Carbohydr Polym, 157, 1298-1305.

Galvin, S., Cahill, O., O'Connor, N., Cafolla, A. A., Daniels, S. \& Humphreys, H. (2013). The antimicrobial effects of helium and helium-air plasma on Staphylococcus aureus and Clostridium difficile. Lett Appl Microbiol, 57, 83-90.

Gharieb, M. M., El-Sabbagh, S. M., Shalaby, M. A. \& Darwesh, O. M. (2015). Production of chitosan from different species of zygomycetes and its antimicrobial activity. Inter J Scien Eng Res, 6, 1-5.

Ghormade, V., Pathan, E. K. \& Deshpande, M. V. (2017). Can fungi compete with marine sources for chitosan production? Int J of Biol Macromol, 104, 14151421 .

Hegemann, D. H., Brunner, H. \& Oehr, C. (2003). Plasma treatment of polymers for surface and adhesion improvement. Nucl. Instrum. Methods Phys Res, B, $208,281-286$

Hong, Y. F., Kang, J. G., Lee, H. Y., Uhm, H. S., Moon, E. \& Park, Y. H. (2009). Sterilization effect of atmospheric plasma on Escherichia coli and Bacillus subtilis endospores. Lett Appl Microbiol, 48, 33-37.

Hu, K. J., Yeung, K. W., Ho, K. P. \& Hu, K. (1999). Rapid extraction of high-quality chitosan from mycelia of Absidia glauca. J Food Biochem, 23, 187-196.

Huang, M., Khor, E. \& Lim, L. Y. (2004). Uptake and cytotoxicity of chitosan molecules and nanoparticles: effects of molecular weight and degree of deacetylation. Pharmac Res, 21, 344-353.

Kitozyme. (2020). Vegetal Chitosan: Unique, patented biopolymer from fungal origin. https://www.kitozyme.com/en/ingredients/chitosan/.

Macedo, M. O. C., Macedo, H. R. A., Silva, G. C., Silva, M. A. M. \& Alves Jr., C. (2012). Estudo comparativo da modificação superficial de membranas de quitosana tratadas por plasma de oxigênio, nitrogênio e hidrogênio. REMAP, 7, 95-103.

Machala, Z., Janda, M., Hensel, K., Jedlovský, I., Leštinská, L., Foltin, V., Martišovitš, V. \& Morvová, M. (2007). Emission spectroscopy of atmospheric pressure plasmas for bio-medical and environmental applications. J. Mol Spectrosc, 243, 194-201.

Marques, J. S., Chagas, J. A. O. D., Fonseca, J. L. C. \& Pereira, M. R. (2016). Comparing homogeneous and heterogeneous routes for ionic crosslinking of chitosan membranes. React Funct Polym, 103, 156-161.

Molina, R., Jovancio, P., Vilchez, S., Tzanov, T. \& Solans. C. (2014). In situ chitosan gelation initiated by atmospheric plasma treatment. Carbohydr Polym, $103,472-479$.

Mondala, A., Al-Mubarak, R., Atkinson, J., Shields, S., Young, B., Senger, Y. S. \& Pekarovic, J. (2015). Direct Solid-State Fermentation of Soybean Processing Residues for the Production of Fungal Chitosan by Mucor rouxii. J Chem Eng, 3, 11-21.

Morent, R., Eyter, N., Desmet, T., Dubruel \& P., Leys, C. (2011). Plasma Surface Modification of Biodegradable Polymers: A Review. Plasma Process Polym, $8,171-190$

Mycodev. (2020). Production. http://mycodevgroup.com.

Napartovich, A. P. (2001). Overview of Atmospheric Pressure Discharges Producing Nonthermal Plasma. Plasm Polym, 6, 1-14.

Paiva, W. S. (2017). Quitosana fúngica na produção de biomaterial membranoso modificado por plasma de descarga em barreira dielétrica (DBD). Mossoró: Federal Rural University of Semiarid, Rio Grande do Norte, Brazil. https://sigaa.ufersa.edu.br/sigaa/public/programa/defesas.jsf?lc=pt_BR\&id=828 .

Paiva, W. S., Souza Neto, F. E. \& Batista, A. C. L. (2014). Avaliação da atividade antibacteriana da quitosana fúngica. Persp Onl: Biol Saúde, 13, 37-43.

Paiva, W. S., Souza Neto, F. E. \& Batista, A. C. L. (2017). Characterization of Polymeric Biomaterial Chitosan Extracted from Rhizopus stolonifer. J Polym Mater, 34, 115-121.

Pankaj, S. K., Bueno-Ferrer, C., O’Neil, L., Tiwari, B. K., Bourke, P. \& Cullen, P. J. (2015). Dielectric barrier discharge atmospheric air plasma treatment of high amylose corn starch films. LWT - Food Sci Technol, 63, 1076-1082.

Pascal, M., Grishina, G., Yang, A. C., Sánchez-García, S., Lin, J., Towle, D., Ibañez, M. D., Sastre, J., Sampson, H. A. \& Ayuso, R. (2015). Molecular Diagnosis of Shrimp Allergy: Efficiency of Several Allergens to Predict Clinical Reactivity. J Allergy Clin Immunol Pract. 3, 521-529.

Polymar. (2020). Nossos produtos. http://www.polymar.com.br/.

Queiroz, M. F., Melo, K. R., Sabry, D. A., Sassaki, G. L. \& Rocha, H. A. O. (2015). Does the Use of Chitosan Contribute to Oxalate Kidney Stone Formation? Mar drugs, 13, 141-158.

Ren, Y., Ding, Z., Wang, C., Zang, C., Zhang, Y. \& Xu, L. (2017). Influence of DBD plasma pretreatment on the deposition of chitosan onto UHMWPE fiber surfaces for improvement of adhesion and dyeing properties. Appl Surf Sci, 396, 1571-1579.

Rosendo, R. A., Andrade, A. A., Figueiredo, A. B. M., Tavares, A. H. dos S., Castro, D. L. de S., Siqueira, R. R. de., Santos, A. dos., Medeiros, M. F. de., Penha, E. S. da., \& Medeiros, L. A. D. M. de. (2020). Estruturas de quitosana utilizadas para regeneração óssea in vivo: uma revisão de literatura. Res Soc Dev, 9 , e891974538. 
Research, Society and Development, v. 10, n. 1, e9210111543, 2021

(CC BY 4.0) | ISSN 2525-3409 | DOI: http://dx.doi.org/10.33448/rsd-v10i1.11543

Salem, T. S., Uhlmann, S., Nitschke, M., Calvimontes, A., Hund, R. \& Simon, F. (2011). Modification of plasma pre-treated PET fabrics with poly-DADMAC and its surface activity towards acid dyes. Prog Org Coat, 72, 168-174.

Sasmazel, H. T. (2011). Novel hybrid scaffolds for the cultivation of osteoblast cells. Int J Biol Macromol, 49, 838-846.

Sathiyaseelan, A., Saravanakumar, K., Mariadoss, A. V. A. \& Wang, M-H. (2020) Biocompatible fungal chitosan encapsulated phytogenic silver nanoparticles enhanced antidiabetic, antioxidant and antibacterial activity, Int J Biol Macromol, 15, 153-163.

Shahidi, S., Ghoranneviss, M. \& Wiener, J. (2015). Improving synthetic and natural dyeability of polyester fabrics by dielectric barrier discharge, J Plast Film Sheeting, 31, 286-308.

Schipper, N. G. M., Varum, K. M. \& Artursson, P. (1996). Chitosans as absorption enhancers of poorly absorbable drugs: Influence of molecular weight and degree of acetylation. Eur J Pharm Sci, 13, 1686-1692.

Signini, R. \& Campana Filho, S. P. (2001). Características e propriedades de quitosanas purificadas nas formas neutra, acetato e cloridrato. Polímeros, 11, 5864.

Silva, A. M., Stamford, T. C. M., Souza, P. M., Berger, L. R. R., Leite, M. V., Nascimento, A. E. \& Campos-Takaki, G. M. (2015). Antifungal Activity of Microbiological Chitosan and Coating Treatment on Cherry Tomato (Solanum lycopersicum var. cerasiforme) to Post-Harvest Protection. Int J Curr Microbiol App Sci, 4, 228-240.

Souza Neto, F. E., Silva, H. C. A., Paiva, W. S., Torres, T. M., Rocha, A. C. P., Bezerra, A. C. D. S. \& Batista, A. C. L. (2017). Quitosana fúngica sobre larvas de nematoides gastrintestinais de caprinos. Arq Inst Biol, 84, 1-5.

Stamford, T. C. M., Stamford, T. L. M., Stamford, N. P., Barros Neto, B. \& Campos-Takaki, G. M. (2007). Growth of Cunninghamella elegans UCP 542 and production of chitin and chitosan using yam bean médium. Electron J Biotechnol, 10, 1-6.

Synowiecki, J. \& Ali-Khateeb, N. A. A. Q. (2003). Production, properties and some new applications of chitin and its derivatives. Crit Rev Food Scien Nutrit, $43,145-171$.

Tayel, A. A. (2016). Microbial chitosan as a biopreservative for fish sausages. Int J Biol Macromol, 93, 41-46.

Theapsak, S., Watthanaphanit, A., \& Rujiravanit, R. (2012). Preparation of Chitosan-Coated Polyethylene Packaging Films by DBD Plasma Treatment. ACS Appl Mater Interfaces, 4, 2474-2482.

Tamburaci, S. \& Tihminlioglu, F. (2017). Diatomite reinforced chitosan composite membrane as potential scaffold for guided bone regeneration. Mat Sci Eng: $C, 80,222-231$

Vital, M. J. S. \& Zilli, J. E. (2010). Protocolo Básico de Coleta de Amostras de Solo para Caracterização da Diversidade Microbiana. Retrieved from: http:// ppbio.inpa.gov.br/protocolos.

Zhang, Z., Xu, Z., Cheng, C., Wei, J., Lan, Y., Ni, G., Sun, Q., Qian, L., Zhang, H., Xia, W., Shen, J., Meng, Y. \& Chu, P. K. (2017). Bactericidal Effects of Plasma Induced Reactive Species in Dielectric Barrier Gas-Liquid Discharge. Plasma Chem Plasma, 37, 415-431.

Zimoch-Korzycka, A., Śmieszek, A., Jarmoluk, A., Nowak, U., \& Marycz, K. (2016). Potential Biomedical Application of Enzymatically Treated Alginate/Chitosan Hydrosols in Sponges-Biocompatible Scaffolds Inducing Chondrogenic Differentiation of Human Adipose Derived Multipotent Stromal Cells. Polymers, 8, 320-344. 